\title{
The Research on Famous International Cruise Brand Building
}

\author{
Zhuling Xu \\ Shanghai University of Engineering Science, Tourism management \\ Shanghai, China \\ 345468912@qq.com
}

\begin{abstract}
In recent fifty years, modern cruise industry is growing at the average annual rate of $8-9 \%$, the growth rate is about two times the average growth rate of output of international tourism. In today's era of rapid development of the cruise industry, through the building of cruise brand, the cruise company can occupy a stable market share in the cruise industry. Proceed from reality, this article analyzes the brand building of many famous international cruise companies and proposes appropriate recommendations.
\end{abstract}

\section{Keywords-cruise brands; brand building; group}

\section{INTRODUCTION}

Cruise travel is cruise will be one or more destination link travel. The cruise is a one-stop service, a cruise is covering the whole travel process aspects, service quality control. At the same time, the cruise industry has a perfect star rating system mature, like the hotel industry. In the cruise can also enjoy the high-grade facilities, to experience the rich entertainment projects, at the same time, relaxation and feel its distinguished, high grade; more can meet all kinds of tourist demand. Cruise travel expenses include meals, accommodation, the boat between the activity fee, entertainment and port transportation. With the continuous implementation of cruise tourism way in the tourism consumption market, the famous international cruises on its cruise brand construction is also more carefully unique brand, launched different according to different demands of tourists and the quality of service characteristics, accurate positioning of the brand, the tourism consumption market have a strong effect.

\section{THE BRAND BUILDING COMPARISON OF FAMOUS INTERNATIONAL CRUISE COMPANIES}

\section{A. Group Management Mode Definition}

Model control group is a mutual influence, mutual support organic system, the process of determining the need to involve three aspects: the first is to determine the special management mode, namely, the headquarters of the subsidiary companies control mode; second is the generalized control model, it not only includes narrowly specific control mode, and including the corporate governance structure, establish headquarters and subordinate division, the role and responsibilities of company selection, concrete form of company organization structure of the important resources in the group control mode and performance management system; the third level is of some important external factors associated with the control modes of thinking, related to the business strategy goals, human resource management, workflow system and management information system.

Cruise culture is born in the development of cruise economy, cruise culture is the cruise industry formed or created with sum of consciousness and behavior norms in the process of economic activities, is a kind of human cultures embodied, is the basic idea of the cruise industry. So the cruise company to build its brand culture and group business model is not the same.

\section{B. Famous International Cruise}

1) Carnival Cruise Brand:Combined with the brand of Carnival Corp, in 2011 49.2\%, share of global cruise market. The company now employs about 3500 people on the shore, most of the employees in the company headquarters in Miami. Carnival cruise lines to provide 28000 jobs worldwide in the cruise ship. The company now has 32 luxury cruise service in the world. Thus, Carnival Cruise for expanding the scale of its brand, although many have different characteristics, it is world famous.

Construction of cruise brands group mode with more standard, enterprise can occupy the safety in the tourist market, reliable feeling, especially in the areas of marine tourism especially pay attention to the security industry is particularly important, to highlight its characteristics in the series, can be the first choice of tourists choose. But the visitors are compared, for its luxurious and the strengthening of the bill.

2) Star Cruises group brand:Star Cruises is "in the Asia Pacific region led the fleet", was founded in 1993, in order to promote the International Asia Pacific cruise tourism development as the goal, the introduction of world-class luxury cruise. In 2011, Star Cruises group (now known as the Genting Hongkong cruise group) as the world's third largest cruise company union.

Star Cruises and without the introduction of American or European style cruise, instead, cruise ship design with the needs and tastes and habits, Asian entertainment and lifestyle, 
and colorful activities. Therefore, Star Cruises introduces a new cruise tourism concept: a rich diet and recreation facilities, international service on the ship, and short-range cruise. The ship is provided with suitable facilities and activities of adults and children, is a new choice of Asian family vacation.

At the same time, Star Cruises also attracted from North America, Europe and Australia to tourists, by taking part in Star Cruises vacation, can glimpse of Asia in different locations and special. Star Cruises actively by various means to build its brand, started it in the visitors' image.

3) The two group comparison:Carnival Cruise through mergers and acquisitions and other means, to become the world's largest, most successful cruises fleet management. Its different cruise company launched its own brand, with young, luxury, happiness in the themes and the establishment of the cruise company brand expansion to become the world's first famous cruise.

But the star cruises with its unique form quickly occupy the Southeast Asian market, Star Cruises to passenger safety, health and comfort as the primary task. Has the world one team the youngest fleet, equipped with the most advanced navigation system and fire control equipment, more additional safety facilities such as automatic sprinkler system. The captain and leadership are especially by Nordic the famous sea area appointment.

Brand positioning and Star Cruises Carnival Cruise group is different, both adhere to choose to highlight their advantages, Carnival group always implement the great advantage in the group, and the star cruises in Asia a firm and its foundation, so the two sides in order to cruise tourism market occupies a space for one person. Of course, the large-scale group can always occupy the major in any market; but in accordance with the brand effect, the Carnival Corp's corporate culture is more dispersed, failed to establish a good effect in the minds of tourists, their advertising is still in the Costa cruises propaganda effect; single relative Star Cruises, also is not a good thing.

\section{Independent Cruise Company's Brand Building}

1) The Yinhai cruise brand building:The Yinhai cruise has always been recognized as luxury cruise industry innovator, experience for guests present large cruise vacation. Line of Yinhai passenger liner cruising have great originality, each port towns through all have their own characteristics, even if the sail in the same area, the line cannot be repeated, can let visitors cruise vacation trip full of freshness.

Brand positioning Yinhai cruise even high-grade, luxury, noble. To this end, Yinhai cruise provides most with private balcony and open-air dining table full sea view suite for guests to choose. But the Yinhai cruise is more the one and only, it is equipped with the people can find out all my most love entertainment facilities on a cruise. From the cruise tourism services, Yinhai cruise has consistently adhered to the service personnel and passengers to the proportion of
$1: 1.4$, so as to create the most private luxury travel to enjoy, the world giants Royal and celebrity worship.

The Yinhai cruise constantly promote their style, they put forward their slogan: Yinhai cruise is the embodiment of your identity. Now take a cruise to Yinhai not only become a kind of luxury fashion, is a symbol of identity and status.

2) Disney Cruise Line Brand Building:Disney cruise cruise line is Disney company independent operation luxury cruise tour service, started in 1998, provides from the east coast of the United States including Florida, the Bahamas, the Caribbean Sea, the west coast of the United States Mexico blue coast and the Mediterranean for many days sailing holiday products.

Brand positioning Disney and Yinhai cruise, brand positioning, it is fantasy and joy, disney cruise line the main customers are aimed at families with young children tourists, have exclusive children's services team disney cruise ship, lead the tourists to children interesting activities at sea, to the safety of children, Disney Cruise Line will be devoted to kids each a boat GPSS call bracelet, so that visitors can know their children in which direction the cruise at any time.

Disney cruise line with other cruise are not the same room facilities, it will be more convenient to consider the family and children, comfortable and modern design, has a spacious and elegant decoration. All the rooms are equipped with separate shower room, is a perfect function specifically for home and design, and for the cruise industry first.

3) Compared the two independent cruise company:Through the above analysis, the Yinhai cruise and Disney Cruise Line the two independent cruise company's brand building are very successful. The reason is they correct brand positioning and unique way of brand promotion. The Yinhai cruise to high-grade, honorable brand positioning, design and noble status symbol of high-grade, is not only a tourist route, cruise and cruise services and equipment. This marketing approach is not to make people remember the Yinhai cruise also very difficult.

While Disney Cruise Line, its brand positioning is based on ship's rich activities as a selling point, to inspire and entertainment all family members, and the quality of service to well-known at Walt Disney World for visitors to magically in every corner can feel. Disney cruise line is the first dedicated to provide young people, it is almost the entire ship designed for children and activities of the company. Disney Cruise is the Disney theme park and resort area of the most growth, a business the best.Cross the same way brand construction, different brand positioning and promotion, this is the successful independent cruise company's brand building mode.

\section{THE FAMOUS INTERNATIONAL CRUISE BRAND}

\section{CONSTRUCTION}

For different types of cruises brand building mode and, for comparison, the famous international cruise brand 
building model from the macro point of view is very similar. Development of innovative brand, different degree of maintenance and management of the brand, to achieve promotion products for different markets different consumer demand means of marketing, but also to make the brand win support among the people, so that consumers can be the first time in the use of cruise products.

The world famous cruise companies are successful because first of all they need to spend time thinking: hope to build brand can represent? The brand out of the ordinary? What makes the brand associated with consumers?

The second is to convey to consumers the information orientation. These ideas should be a long-term business philosophy. Brand seems very quickly, it is a long-term process. If the company made a commitment to consumers, but cannot turn it in cash or cannot always keep your promises, and ultimately the brand will still fail, because the consumers will have tangible and intangible test of a brand.

The last is to adhere to the principle of simplicity. From the internal corporate brand building, if employees don't know their business, how to let consumers know yourself. Only let consumers fully understand their own, from the aspects of enterprise to win consumers. With these three elements, the remaining work is to find marketing battlefield, you pay attention to every key point of brand building, and strive to create the world famous brand.

\section{CONCLUSION}

Through the above data and the generalized analysis of brand positioning, in contrast, the macroscopic angle to the international famous brand to brand building cruise process construction fine one one anatomy, visible, the potential of the cruise industry makes the cruise market has become increasingly active.

Research shows that, the construction of famous international cruise brands all so-called successful brand, is to make the brand to consumers around the world heart. From a high of four principles, shaping the brand look far ahead from a high plane, sweep down irresistibly from a commanding height, Gaokaidizou, sleep peacefully; to five key factors: high quality, have a style of one's own, leading strategy, integrated marketing force, elegant culture, without attention. The key to cruise and the company's success is that brand success, not only to the immediate interests and reputation, more important is the long-term brand strategy planning.

Because the domestic cruise market are still under cultivation, analysis and Research on China's tourism market present stage mainly focus on the analysis of the characteristics of cruise tourism market and marketing strategy. Related learning international cruise group construction of cruise brands, focusing on relevant experience in market promotion and brand long-term research does not see more.

Closely linked with the construction of cruise brand is not only has a long experience great accumulation or enormous financial background, even more important is the enterprise culture heritage. Most cruise brand success mainly is still standing in the consumers point of view to think, thinking about how to develop the consumer favorite and the need of tourism products. This point is not only in China cruise industry field, but also need to improve in the field of tourism product development.

\section{REFERENCES}

[1] Wang Guanlan, Lou Jia Jun. Distribution features of international cruise companies market and Its Enlightenment to Shanghai [J]. Journal of Henan Business College,.2008 (04): 59-64.

[2] Zhang Feng, Lin Shanlang. Status and trends of cruise industry development international analysis [J]. China port of.2008 (08).

[3] Lu Yuexiang. On the study in brand awareness [J]. Journal of China Youth University for Political Science,.2006 (06): 98-101.

[4] Wu Jianhai. The cruise tourism market development of Chinese business [J]..2010 (05): 279-280.

[5] Zhang Yanqing, a wave, Fan Ying Jie. The cruise tourism industry and economic characteristics, development trend and Its Enlightenment to China [J]. Journal of Beijing International Studies University,.2010 (7): 26-33.

[6] Wang Ying, Xu Yueyi. The international cruise tourism development and Enlightenment of Zhejiang province [J]. Jiangsu theory,2010 (9): 123-126.

[7] Cheng Juehao global cruise tourism market development research [J]. world shipping.2004 (08): 25-27. 